\title{
El cómic como experiencia (un Beta-test de la narratividad del medio a partir de la obra de Begoña García-Alén) ${ }^{1}$
}

\section{Comic as Experience (Beta-testing the Comic Narrativity Based on Begoña García-Alén's Works)}

\section{Óscar García López}

Óscar García López es licenciado en Teoría de la Literatura y Literatura Comparada por la Universidad Complutense de Madrid. Actualmente está realizando en ella su doctorado enfocado a la investigación de la metalepsis en el cómic. Ha publicado varios artículos en las revistas digitales Tebeosfera y CuCo, Cuadernos de Cómic, ha coordinado y contribuido al libro de ensayos Watchmen: Radiografías de una explosión (Modernito Books, 2013) y participado en los libros sobre series de televisión Los héroes están muertos (Dolmen, 2014) y Yo soy más de series (Esdrújula, 2015).

Fecha de recepción: 29 de diciembre de 2018

Fecha de aceptación definitiva: 8 de abril de 2019

${ }^{1}$ Este artículo es el resultado de una elaboración posterior y más profunda de la comunicación «Los límites de la narración en el cómic. Un test de elasticidad sobre la obra de Begoña García-Alén» presentada en Unicómic xx. Congreso Internacional de Estudios Universitarios sobre el Cómic en septiembre de 2018. 


\title{
Resumen
}

Las particularidades del cómic pueden favorecer su empleo como soporte en el que desarrollar un relato pero esta circunstancia no implica que ese potencial narrativo se imponga como condición exclusiva y excluyente. Las obras de un grupo emergente de autoras y autores que están poniendo a prueba los convencionalismos del medio y expandiendo sus fronteras hacia nuevos territorios han reavivado un debate sobre el estatuto del cómic en el que late de fondo una pregunta: ¿qué es la narrativa? Adoptando como herramienta de análisis la teoría narratológica de Monika Fludernik — que reformula desde una perspectiva cognitiva los criterios estructuralistas empleados para definir lo narrativo-, este texto intenta trazar un itinerario por esas nuevas manifestaciones liminales del cómic - en cuyo última frontera podríamos situar la abstracción — utilizando como mapa la obra de Begoña García-Alén.

Palabras clave: Begoña García-Alén, cómic abstracto, cómic vanguardista, Monika Fludernik, narratología cognitiva

\begin{abstract}
The particularities of the comic medium can favor its use to create stories but this circumstance does not imply that this narrative potential is imposed as an exclusive condition. The works of an emerging group of authors who are testing the conventions of the medium and expanding their borders to new territories have revived the debate on its status and situated on the foreground a key question: what is narrative? Adopting as analytical tool the narrative theory of Monika Fludernik - that reformulates from a cognitive perspective the structuralist criteria used to define what a narrative is - this text tries to trace an itinerary through those new liminal comic manifestations - in whose limit we could find abstract comics - using the work of Begoña García-Alén.
\end{abstract}

Keywords: abstract comics, avant-garde comics, Begoña García-Alén, cognitive narratology, Monika Fludernik

\section{Cita bibliográfica}

García LóPez, Ó. «El cómic como experiencia (un Beta-test de la narratividad del medio a partir de la obra de Begoña García-Alén», en CuCo, Cuadernos de cómic, n. 13 (2019), pp. 27-50. 
Reconocer en público la práctica de la narratología puede entenderse, hoy en día, como una confesión equivalente a admitir el gusto por las películas de serie B. Puede sentirse como la expresión terapéutica de un placer culpable con la única intención de conjurar el remordimiento arrastrado por el ejercicio de algo anómalo, impropio, seguramente atávico. Algo teóricamente pre-postmoderno y pre-postestructuralista. Algo absolutamente carente de cualquier tipo de hype a nivel académico. La narratología puede malentenderse en estos términos y la responsabilidad de este malentendido corresponde indudablemente a los errores de sus practicantes y docentes. Entre ellos probablemente el mayor haya sido presentarla de una forma en exceso mecanicista, jugando a identificar las categorías propuestas por Genette sin llegar más allá: este es el narrador y es de tipo xyz-diegético, aquí vemos una prolepsis, un poco más adelante una analepsis. Actuando así, como si su finalidad residiera en sí misma, puede haberse prescindido de hacer énfasis en su condición instrumental, olvidando incidir en su valor real que no es otro que of recer un potente juego de herramientas al servicio general de la teoría, el análisis y la crítica.

Esa percepción limitada de la disciplina podría hacer suponer que se ha mantenido anclada en el estructuralismo que la caracterizó en sus inicios, en esa comprensión de los textos narrativos como arquitecturas segmentadas en varios estratos que podrían reducirse a un mínimo de dos. Un nivel en el que se desarrollaría la acción narrativa en una secuencia de eventos, siguiendo un orden cronológico y protagonizada por personajes antropomórficos, que dependiendo de la corriente teórica se ha identificado como fabula, o story, o bistoire; o que incluso resulta posible asimilar — con cierta intención generalizadora - al significado del signo lingüístico saussureano. Y otro nivel en el que la figura enunciativa de un narrador se encargaría de reorganizar esos eventos, dotándolos de un sentido teleológico más que cronológico, creando una trama significante $-\mathrm{o}$ syuzhet, o plot, o discourse - ${ }^{2} \mathrm{El}$

2 El primer grupo de teóricos en identificar una estructura binaria en los textos narrativos fueron los formalistas rusos. En concreto Víktor Shklovski en su obra Sobre la prosa literaria (1925 [1971, traducido al español]) fue el primero en distinguir entre fabula y syuzhet, entendiendo la fabula como el material primario que recibe una forma artística en el syuzhet. Aunque fue Boris Tomashevski quien en su manual titulado Teoría de la Literatura (1925 [1982, traducido al español]) extendió el uso de ambos conceptos asociando la fabula a una secuencia de motivos conectados por relaciones temporales y causales y el syuzhet a esos mismos motivos según aparecen en la obra literaria. El modelo que distingue entre la pareja de conceptos story/plot se asocia a la crítica literaria norteamericana y fue propuesto originalmente por el escritor y teórico E. M. Forster en su Aspectos de la novela (1927 [1983, traducido al español]). Las relaciones de causalidad se convertían en el principal elemento diferenciador que Forster ilustró con el célebre ejemplo de la frase «The king died and then the queen died» que así presentada constituiría una story pero que transformada en "The king died and then the queen died of grief» se convertiría en un plot. A esta misma terminología recurrirían otros teóricos estadounidenses como Edwin Muir, Cleanth Brooks y Robert Penn Warren. Los estructuralistas franceses fueron los primeros en comenzar a traducir los textos de los formalistas rusos a mediados del siglo xx y retomaron los conceptos de fabula/syuzhet reelaborándolos y transformándolos en el par histoire/discours introducido por Emile Benveniste en sus 
lector, abocado a ejercer de detective, al enfrentarse a un texto vería su misión consagrada al reordenamiento de los sucesos que componen la cadena causal del relato con la finalidad de averiguar su significado. Así, en este modelo, se plantearía lo narrativo como la búsqueda de un sentido que puede ser desvelado. Al reducir el relato a un juego de combinatoria con eventos, que resultarían equiparables a las piezas de un puzle, la observación de su totalidad a vista de pájaro permitiría reconstruir esa significación oculta o postergada hasta ese momento epifánico. Meir Sternberg ha llegado a sugerir que la catarsis aristotélica resultaría un efecto secundario de este proceso de desentramado. La epifanía, según él, tendría lugar al experimentar el receptor una nueva visión holística e iluminadora en el instante congelado de un salto imposible, durante la acrobacia infinitesimal que le arroja desde la linealidad del tiempo del relato a la construcción bidimensional que va erigiéndose en su memoria y permite una contemplación simultánea de todos los eventos que componen la historia. ${ }^{3}$

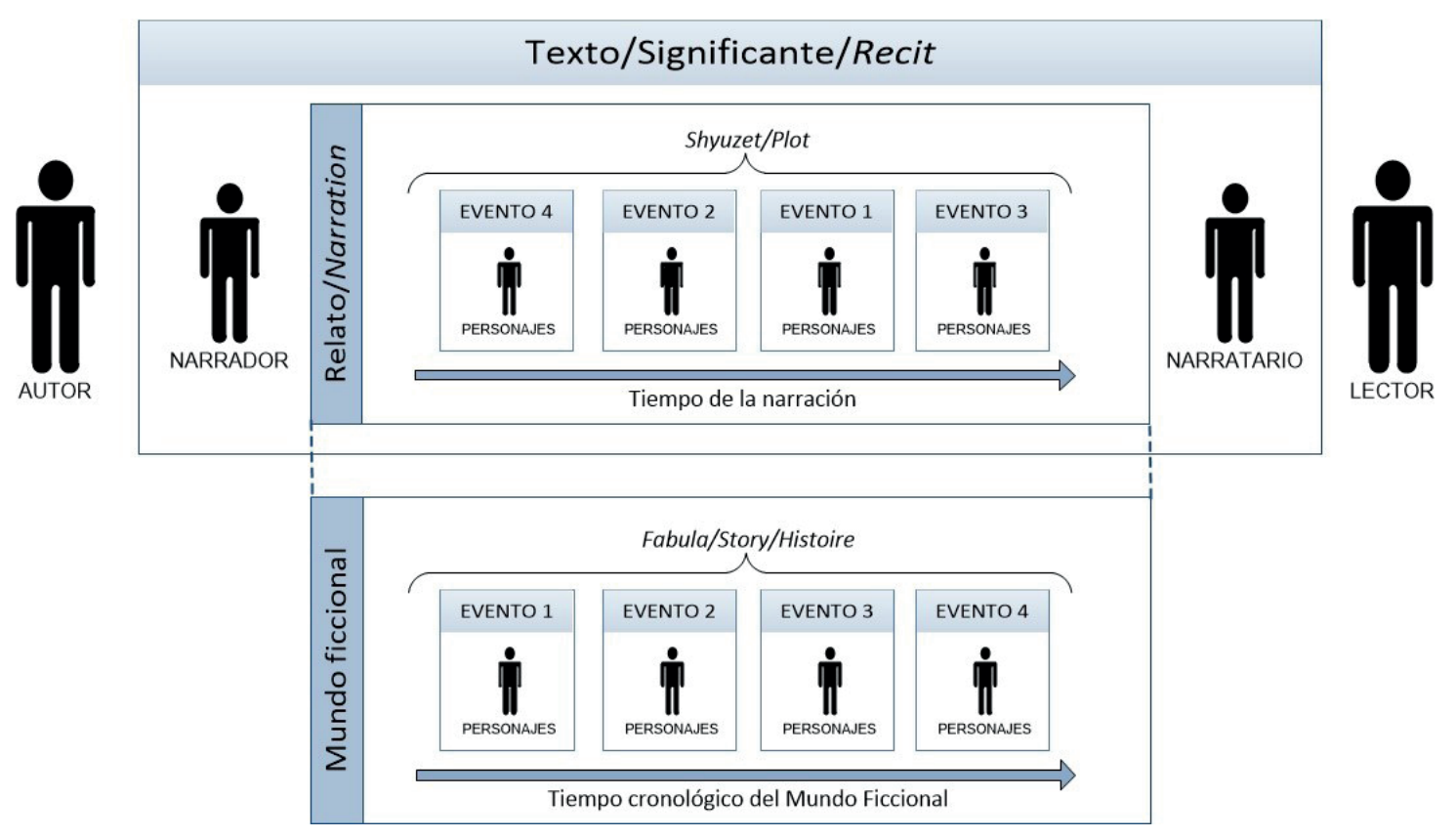

FIG. 1. Esquema de la composición narrativa según la visión estructuralista. Elaboración propia.

estudios de lingüística y posteriormente retomados en el ámbito de lo literario por Tsvetan Todorov. En el modelo de Genette se mantendría el estrato histoire asimilado al significado narrativo y el nivel del discours se vería escindido en dos: por una parte, el término recit haría referencia al significante narrativo, es decir al propio discurso y con el concepto narration aludiría a la situación narrativa real que enmarca a la acción relatada. Esta información se puede ampliar en la entrada online de la página web The living handbook of Narratology de la Universidad de Hamburgo, en la sección «Narrative Constitution» creada por Michael Scheffel: http://www.lhn.uni-hamburg.de/article/narrative-constitution (última consulta el 12 de octubre de 2018).

3 Sternberg, M. Citado en Fludernik, M. Towards a Natural Narratology. London, Routledge, 1996, p. 243. 
Esa búsqueda que subyace al modelo narratológico estructuralista y que se podría emparentar con las corrientes positivistas propias de la modernidad, ese deseo de alcanzar la visión global de una secuencia de eventos que diagramada recuerda tanto a la sucesión de viñetas en un cómic, facilitaría la traslación de este modelo a nuestro medio y podría hacernos pensar que la narratividad forma parte de su ADN, como un extenso grupo de teóricos sostienen. En su estudio fundacional Román Gubern ya definía el cómic como una «estructura narrativa formada por la secuencia progresiva de pictogramas, en los cuales pueden integrarse elementos de escritura fonética» ${ }^{4}$ y el caracter general de esta percepción se ha visto confirmado por otros críticos como Jesús Jiménez Varea al afirmar que: «Un repaso de algunas definiciones del medio evidencia una opinión compartida casi unánimemente por los teóricos que respalda la vocación narrativa del cómic de la que cualquier lector es consciente sin necesidad de mayor reflexión». ${ }^{5}$

Incluso Thierry Groensteen ha llegado a mostrarse más tajante al sentenciar que «for comics, liberation from narrative and liberation from its own self would be one and the same thing».6

Pero las aproximaciones de carácter estructuralista que comparten esta filosofía que - de manera simplificada - acabamos de presentar pueden no resultar herramientas de análisis apropiados para afrontar ciertos tipos de texto que seguimos entendiendo como narrativos. Ante esas limitaciones y por otros motivos la narratología ha ido evolucionando y viendo la emergencia de una serie de corrientes que algunos autores han englobado bajo la denominación de narratología «postclásica». El término, acuñado por David Herman en su artículo «Scripts, Sequences, and Stories: Elements of a Postclassical Narratology», ${ }^{7}$ abarcaría un conjunto de aproximaciones abiertas a la integración de nuevas metodologías e hipótesis de investigación. Pero, como el propio Herman sostiene, sin que eso suponga una renuncia a los cimientos estructuralistas de la disciplina:

[...] in its postclassical phase, research on narrative does not just expose the limits but also exploits the possibilities of the older, structuralist models. In much the same way, postclassical physics does not simply discard classical Newtonian models, but rather rethinks their conceptual underpinnings and reassesses their scope of applicability. ${ }^{8}$

${ }^{4}$ Gubern, R. El lenguaje de los comics. Barcelona, Ediciones Península, 1972, p. 35.

${ }^{5}$ Jiménez Varea, J. Narrativa gráfica. Narratología de la historieta. Madrid, Editorial Fragua, 2016, p. 12.

${ }^{6}$ Groensteen, T. Comics and Narration. Jackson, University Press of Mississippi, 2011 [2013], p. 176. [«Para la historieta, liberarse de lo narrativo y liberarse de su propio ser es una y la misma cosa»]. Todas las traducciones que aparecen en las notas al pie son propias.

7 Herman, D. «Scripts, Sequences, and Stories: Elements of a Postclassical Narratology», en PMLA, vol. 112, n. 5 (octubre 1997), pp. 1046-1059.

${ }^{8}$ Herman, D. «Introduction», en Narratologies: New Perspectives on Narrative Analysis. Ed. David Herman. Columbus, The Ohio State University Press, 1999, p. 3. Citado en Alber, J. y Fludernik, M. «Introduction», en Postclassical Narratology. Approaches and Analyses. Columbus, The Ohio State University Press, 1999, p. 1. [«(...) en su fase postclásica la investigación en narrativa no solo expone los límites, también explora las posibilidades de los antiguos modelos estructuralistas. Del mismo modo que la física postclásica 
Dentro de estos nuevos enfoques es posible distinguir varias tendencias que se pueden agrupar en dos corrientes principales. Por un lado, han ido surgiendo estudios narratológicos enfocados a una aplicación contextual y con una perspectiva ideológica que se han ocupado de analizar obras desde ópticas nuevas como el feminismo, el postcolonialismo o lo queer. ${ }^{9} \mathrm{Y}$, por otro, la narratología clásica desarrollada en el ámbito de la literatura se ha visto enriquecida con la ampliación de su campo de estudio a medios diferentes y con la introducción de nuevos conceptos procedentes de las ciencias cognitivas. A esta última tendencia podemos adscribir la obra teórica de Monika Fludernik que nos va a servir para intentar iluminar desde un ángulo distinto los cómics de Begoña García-Alén.

En el modelo narratológico de Fludernik el componente fundamental pasa a ser lo que ella define como «experientiality», y que a falta de un término mejor traduciremos como «experiencialidad». Este concepto integraría las diferentes formas de representar la experiencia humana mediada por la consciencia de un individuo. La experiencialidad incorpora y marginaliza la trama: ya no es necesario que se dé esa sucesión de eventos para identificar lo narrativo, únicamente son condiciones imprescindibles la presencia de un individuo y la manifestación de su consciencia. La narratología natural, según la denomina Fludernik, asume también una perspectiva constructivista: los textos narrativos serían aquellos que se leen narrativamente. $Y$ en ese proceso entrarían en juego una serie de categorías importadas de las ciencias cognitivas. La más importante sería el concepto de esquema, entendido como un patrón de memoria basado en experiencias previas que el ser humano emplea para afrontar otras nuevas y dotarlas de significado. Dentro de los esquemas adquiriría especial importancia un tipo concreto, los scripts o guiones, que recogerían secuencias ordenadas de eventos asociados a una experiencia particular y que servirían para lograr adaptarnos rápida y eficazmente a ella en instancias sucesivas. ${ }^{10}$ Así, podríamos identificar un ejemplo de script prototípico para la experiencia «comer en un restaurante» en la siguiente serie específica de eventos: esperar a que nos sienten en una mesa, recibir la carta y pedir la bebida, escoger los platos deseados y trasladar nuestra elección al camarero, recibirlos en un orden concreto y finalmente pagar, dejar propina y salir del restaurante. Los viajes al extranjero ofrecen una posibilidad muy interesante de observar en nosotros mismos el funcionamiento de estos scripts inconscientes cuando, como turistas, nos enfrentamos a situaciones aparentemente familiares que pueden no ajustarse con precisión a los esquemas que manejamos. Lo mismo

no se limita a descartar los modelos newtonianos clásicos, sino que reformula sus conceptos fundamentales y reconsidera el alcance de su aplicación»].

9 Dentro de la corriente de la narratología feminista destacan figuras como Susan Lanser, Robyn Warhol o Ruth Page que han incorporado la perspectiva de género para reconsiderar las categorías fundamentales del análisis narratológico: autor, lector, narrador, narratario. Judith Roof ha propuesto un proyecto narratológico que desvela la predominancia temática de una sexualidad heteronormativa frente al tratamiento de la temática homosexual en la narrativa. Otros críticos, como Brian Richardson o Dorothy McHale, han orientado sus estudios hacia la ficción postcolonial. Se puede encontrar un informe más detallado de los estudios realizados en estos ámbitos en: Alber. J y Fludernik M. Op. Cit.

${ }^{10}$ Herman, D. (1997). Op. cit., p. 1047. 
sucede al acercarse a cierto tipo de cómics actuales, como los realizados por Begoña García-Alén, en los que podemos llegar a sentirnos turistas en territorio desconocido.

Empleando estos conceptos, Fludernik sustenta su modelo constructivista sobre una estructura de cuatro niveles en los que sitúa diferentes conjuntos de esquemas cognitivos. En un primer nivel ubicaría un grupo de esquemas transculturales como los relacionados con la comprensión de los procesos humanos de agencia y consecución de objetivos, la interpretación de las relaciones causa-efecto en una serie de eventos o el reconocimiento de las emociones y las motivaciones. El segundo nivel incorporaría cuatro perspectivas diferentes que se pueden emplear para acceder a un relato y que se relacionan así con la mediación narrativa. Estos esquemas se corresponderían con las experiencias «telling» (contar), "viewing» (percibir), «experiencing» (experimentar) y «acting» (actuar). En el nivel tres se recogerían parámetros cognitivos relacionados con situaciones narrativas conocidas entre las que se incluirían la distinción de géneros —entendidos como marcos cognitivos extensos- y categorías narratológicas como: narrador, reordenamiento cronológico, omnisciencia... En este nivel sí se observaría una dependencia y variación en función de la cultura a la que pertenezca el receptor. Y por último, el nivel cuatro estaría relacionado con la habilidad del lector para asignar la condición narrativa a un texto y se entendería como un proceso dinámico que tiene lugar durante la lectura recurriendo a esquemas de los niveles anteriores. ${ }^{11}$

\begin{tabular}{|c|c|}
\hline$\frac{\geq}{\frac{\geq}{z}}$ & $\begin{array}{l}\text { Proceso de narrativización recurriendo a los } \\
\text { esquemas de los niveles I a III. }\end{array}$ \\
\hline$\frac{\equiv}{\frac{\bar{\alpha}}{z}}$ & $\begin{array}{l}\text { Esquemas culturales relacionados con la narrativa } \\
\text { y sus categorías. }\end{array}$ \\
\hline$\frac{\bar{\nu}}{\frac{\mathrm{Q}}{\mathrm{z}}}$ & $\begin{array}{l}\text { Esquemas de acceso al relato: «telling», «viewing», } \\
\text { «experiencing», «acting». }\end{array}$ \\
\hline$\overline{\bar{\nu}}$ & $\begin{array}{l}\text { Esquemas cognitivos transculturales relacionados } \\
\text { con la experiencia humana primaria. }\end{array}$ \\
\hline
\end{tabular}

FIG. 2. Niveles cognitivos que participan en la narrativización de un texto. Elaboración propia.

${ }_{11}$ Fludernik, M. Op. cit., pp. 31-38. 
Aunque Fludernik extiende su propuesta a otros medios distintos al literario, considerando la narratividad de teatro y cine ${ }^{12}$ - en ningún momento la del cómic-, no profundiza en cómo se incorporaría la medialidad a su modelo de cuatro niveles. Si entendemos que las diferencias en el acceso a una narración presentada en un medio residen en las propiedades semióticas de su discurso específico, en ese código que el receptor interpreta para acceder a la acción representada, el nivel III parece resultar el estrato más apropiado para ubicar los esquemas cognitivos asociados a las peculiaridades intermediales. En el caso de la historieta, que al combinar lenguaje verbal e imágenes posee un nivel de codificación complejo en comparación con la literatura, podemos aventurar algunos esquemas que representen el acceso prototípico del lector a su discurso.

Considerando la evolución diacrónica del medio asumiremos la predominancia de una estructura de página organizada en una secuencia vertical de varias tiras horizontales, compuestas de viñetas que reproducen eventos sucesivos cronológicamente, herencia de los formatos que moldearon el medio en su eclosión masiva a finales del siglo xIx y principios del xx en la prensa norteamericana y que ha perdurado hasta nuestros días. Tomando esta composición de página como referencia — erigiéndola en prototipo-, el acceso del lector al texto se atendría a un esquema cognitivo en el que su mirada trazaría un patrón en $Z$ sobre la página, deteniéndose en cada una de las viñetas para decodificar sus contenidos.

Del mismo modo podemos establecer una compresión elemental del código en el interior de la viñeta a partir del empleo más extendido y convencional de sus recursos. Para clasificar el uso de estos elementos vamos a matizar la frecuente distinción que se realiza en la historieta entre imagen y texto proponiendo otra en la que estableceremos una diferencia entre dos dimensiones de orden más générico: la mimética y la diegética, que no estarían asociadas exclusivamente al lenguaje verbal o a los signos icónicos.

En este modelo - entendido también como prototipo- los bocadillos de texto y de pensamiento, comparten el espacio de representación y una función imitativa primaria con la imagen, su ocurrencia tiene lugar en ese mismo espacio/tiempo definido en el interior de la viñeta y, por tanto, formarían parte de la dimensión que hemos llamado mimética. Lo diegético, que sucede en un tiempo diferente - el que marca el acto de narrar empleando el lenguaje, generalmente vinculado al tiempo verbal pretérito- quedaría entonces reservado a los textos que se muestran en cartuchos asociados a la voz de un narrador. Jesús Jiménez Varea destaca también este aspecto apuntando hacia la misma distinción que nosotros deseamos ampliar:

En el cómic, el concepto de narración se encuentra íntimamente ligado a la verbalización inserta en los textos de apoyo de las viñetas y en los cartuchos situados entre ellas. Tanto es así que estos reciben frecuentemente la denominación de textos diegéticos, haciéndolos depositarios parciales

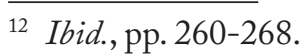


en la historieta de la tradicional oposición mímesis-diégesis instituida por Aristóteles y recuperada más recientemente por los teóricos de la narrativa. ${ }^{13}$

\section{PÁGINA}

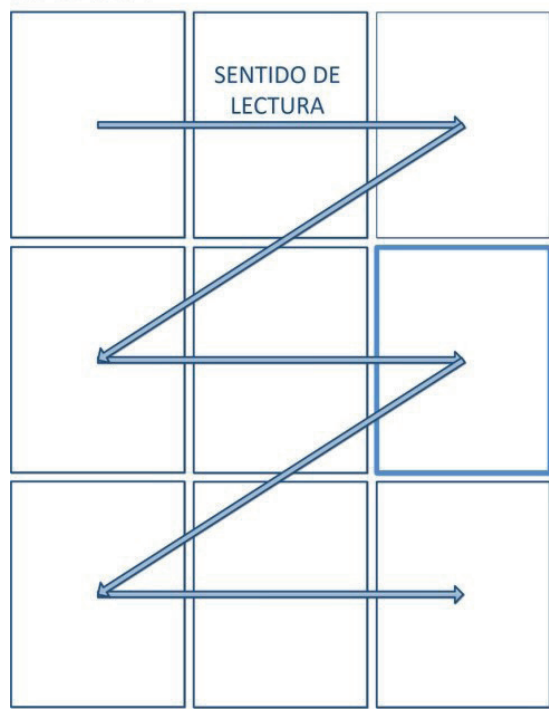

VIÑETA

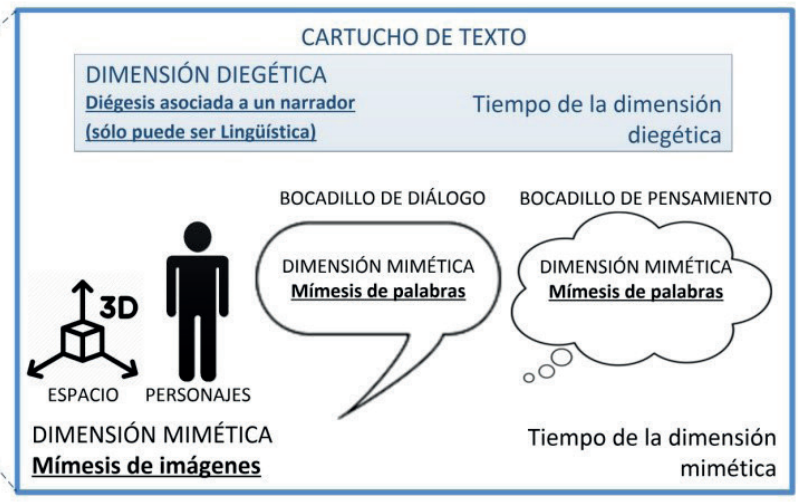

FIG. 3. Esquema prototípico del acceso al discurso del cómic asociado al nivel III del modelo de Fludernik. Elaboración propia.

Si prestamos atención a cómo se despliega esta doble temporalidad diegética y mimética tomando como ejemplo una serie de viñetas concreta podemos sumar alguna otra conclusión que complete ese modelo prototípico que estamos estableciendo y que nos servirá para considerar las desviaciones que tienen lugar en los cómics de García-Alén. Observemos la primera página de Maus de Art Spiegelman donde podemos comprobar cómo en la dimensión diegética, aislada en los cartuchos de texto, se manifiesta una voz empleando como tiempo verbal el pretérito imperfecto que, al representar acciones en curso, todavía inacabadas, resulta idóneo para la narrativa verbal. Ese narrador diegético introduce sus recuerdos de la niñez que inmediatamente se trasladan a la dimensión mimética como imágenes en la viñeta, como personajes que hablan e interactúan entre sí. Los diálogos que entablan comparten la misma temporalidad que su representación dibujada: la indexicalidad implícita en el bocadillo despliega las palabras de los personajes como un acto de habla en un determinado instante. El tiempo que rige la dimensión mimética —en comparación con el verbal que gobierna la diegética - carece de pasado o futuro, se manifiesta en un presente eterno o atemporal. Al conjugarse ambos en la viñeta parece establecerse una relación de precedencia de la dimensión diegética sobre la mimética, la narración parece fluir desde el simbolismo del lenguaje verbal hacia la iconicidad de la imagen siguiendo un proceso de concreción semiótica, avanzando desde ese pasado del relato en palabras encerrado en los cartuchos al presente de la imagen en la viñeta. Aproximándonos progresivamente a la narración, como

${ }^{13}$ Jiménez Varea, J. Op. Cit., p. 95. 
si empleáramos una lupa para acercarnos a las palabras de un texto e ir ampliando el contorno de sus letras, acercándonos más y más hasta que solo llegáramos a percibir la negrura de la tinta con la que están escritas, sin detener nuestra inmersión en el relato hasta que de la oscuridad comenzaran a adquirir forma las imágenes que representan esos caracteres en tinta. Esta relación entre lo diegético y lo mimético en el cómic puede considerarse también un desarrollo prototípico del fenómeno narrativo en este medio.

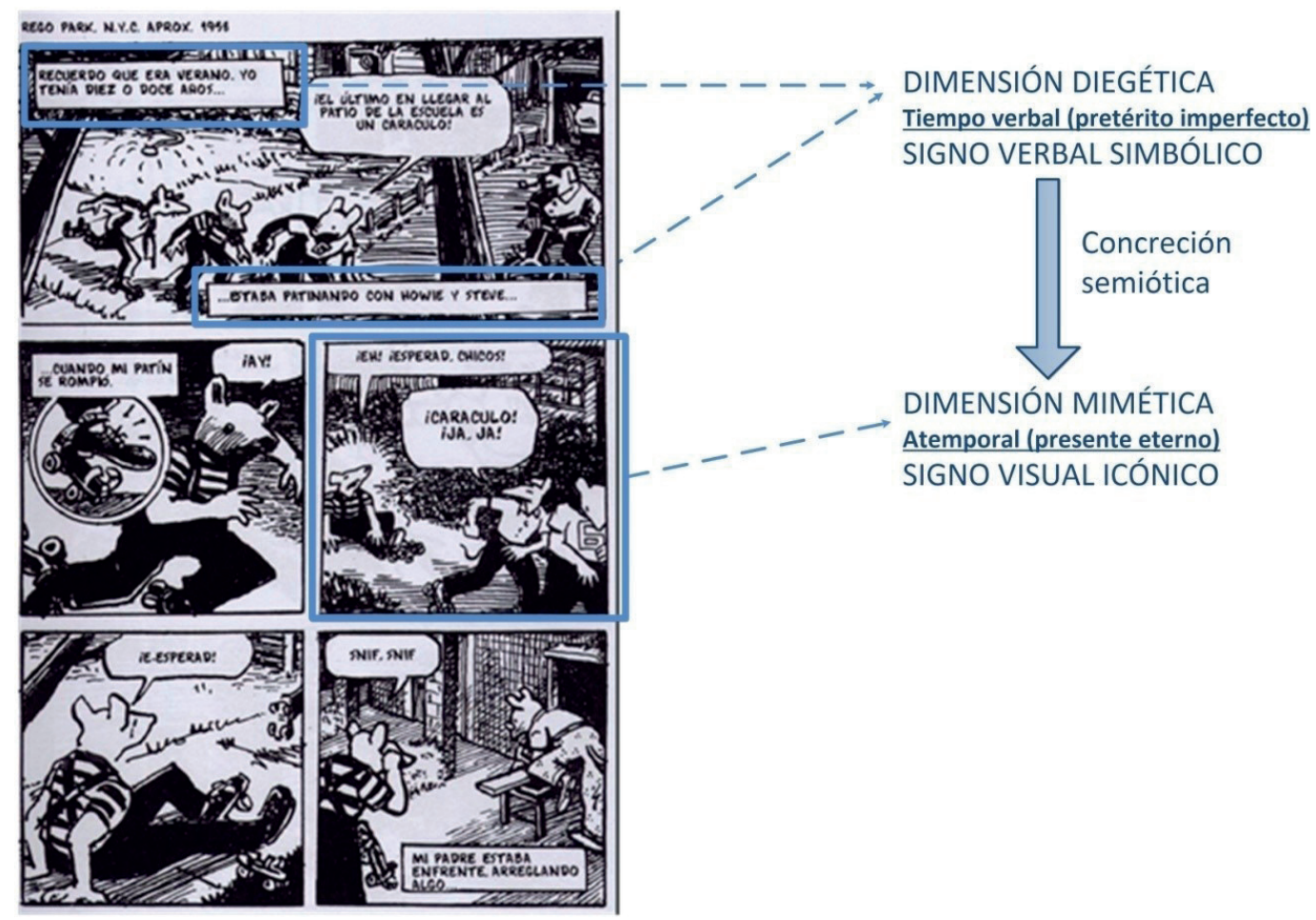

FIG. 4. Temporalidad en la dimensión diegética y mimética. Precedencia de la diégesis sobre la mímesis. Elaboración propia.

El grado de narratividad de un texto establecería una correlación con el nivel de éxito alcanzado por el lector en ese proceso de aplicación sistemática de sus esquemas cognitivos previos. Y en el caso de nuestro medio, para asimilar el discurso altamente codificado propio de la historieta, entrarían también en juego estos esquemas específicos, de los que hemos aventurado un conjunto de prototipos. Cuando el lector se enfrente a un texto que en un primer momento le resulte incomprensible o incoherente buscará un marco cognitivo que le sirva para naturalizar esas inconsistencias y dotarlas de significado, intentará hacer familiar lo extraño recurriendo a su repertorio de esquemas. En casos extremos en los que la sintaxis o la referencialidad se ven destruidas con fines estilísticos, o la enunciación narrativa se fragmenta en secuencias de textos yuxtapuestos difíciles de organizar de una manera coherente y cohesionada o desaparecen los escenarios, los personajes y sus consciencias, el proceso de narrativización finalmente fracasaría. Aunque, según Fludernik, poseemos un alto grado de tolerancia a las inconsistencias, el caos y la ambigüedad cuando aplicamos 
nuestros esquemas cognitivos a la realidad. ${ }^{14}$ Intentaremos ponernos a prueba como lectores con algunas obras de Begoña García-Alén.

Esta autora ha sido considerada una de las representantes emblemáticas de una innovadora forma de hacer cómic que un grupo de jóvenes artistas, formados en el ámbito de las bellas artes y el diseño gráfico, están afianzando con solidez dentro del mercado alternativo y la autoedición. Para señalar la distancia que separa las prácticas de esta tendencia respecto al cómic tradicional los críticos han empleado distintos calificativos. Gerardo Vilches se ha referido a esta corriente transformadora como «vanguardia» apuntando las dificultades que supone afrontar estas obras desde una perspectiva crítica debido a las carencias que sufrirían las categorías narratológicas clásicas:

Hemos manejado durante años valores que funcionaban $-\mathrm{o}$ tal vez parecían funcionar-, pero ¿cómo aplicar conceptos como «secuencia», «narrativa» o «argumento» a trabajos donde lo que sucede no importa, la acción queda reducida a una mera anécdota, o incluso no hay personajes humanos? ¿Cómo podemos valorar con ellos obras en las que el relato carece de importancia? [...] las viejas categorías no tienen apenas aplicación: necesitamos herramientas nuevas para poder analizar una vanguardia que rechaza las reglas, y para ello es esencial que nos formemos, pero también que mantengamos la mente abierta y receptiva a nuevas propuestas. ${ }^{15}$

Horacio Muñoz Fernández ha preferido el término «posnarrativo» para referirse al mismo grupo de autores —entre los que recurren los nombres de García-Alén, Patrick Kyle, Ana Galvañ, Gabriel Corbera, o Yuichi Yokoyama - de forma que identifica en ellos una poética donde la imagen cobra una especial relevancia y en ocasiones desvinculándolos por completo de lo narrativo - aspecto en el que discrepamos, creyendo que pueden asumirse como sinónimos los conceptos de narración y trama, cosa que a nuestro entender no son-. Dentro de su muy interesante aproximación sostiene que:

El cómic posnarrativo muestra una indiferencia, liberación o ausencia de narrativa con las que intenta escapar del carácter convencional e instrumental de los materiales expresivos de la mayoría de los cómics mainstream, pero también de los excesos literarios y narrativos de la novela gráfica o del carácter informativo del cómic periodístico. Para los autores que se mueven dentro de las coordenadas del cómic posnarrativo, los dibujos y las viñetas no se usan con una función comunicadora para vehicular una narración de manera transparente sino que se busca sustraerlos de ese papel para que la imagen y el dibujo adquieran un nuevo protagonismo. [...] En el cómic posnarrativo asistimos a un triple proceso de desnarrativización, desantropormofización y despsicologización que produce, respectivamente, una revalorización del tiempo, el espacio y las figuras humanas. ${ }^{16}$

${ }^{14}$ Fludernik, M. Op. cit., pp. 202-233.

15 Vilches, G. «La vanguardia y su crítica», en Revista Kamandi (7 de diciembre de 2016). Disponible en http://www.revistakamandi.com/2016/12/07/la-vanguardia-y-su-critica/ (Última consulta 15/10/18).

16 Muñoz Fernández, H. «Notas sobre el cómic más allá de la narración» (mayo 2017). Disponible en https:// es.paperblog.com/notas-sobre-el-comic-mas-alla-de-la-narracion-4364575/ (última consulta 22/11/18). 
Thierry Groensteen, con una elaboración teórica extensa, recogida en su obra Comics and Narration, ${ }^{17}$ no identifica en esta tendencia un patrón estilístico único sino que distingue un espectro gradual que abarcaría desde manifestaciones afiliadas a la abstracción hasta historietas que define como infranarrativas. Al primer grupo pertenecerían las compuestas por series de imágenes abstractas sin conexiones lógicas o cronológicas asociadas a un mundo ficcional, sobre las que afirma lo siguiente:

What exactly is it, then, that we see on a comics page made up of abstract images? Two thingsthat need to be distinguished from each other. [...] Firstly, visual content: colors, lines, forms organized into motifs. These abstract «images» interact with each other. They establish relationships of position, contiguity, intensity, repetition, variation, or contrast, as well as dynamic relationships of rhythm, interwovenness, etc. In principle, nothing in this list pertains to narration, which is why I alluded above to a series, rather than a sequence, of drawings. [...] Secondly, what is shown by an abstract comics page is the spatio-topical apparatus of comics (henceforth referred to as the apparatus). This is a space that is demarcated and compartmentalized, within which frames enter into spatial relationships and compose an organized totality. ${ }^{18}$

Mientras que en ese segundo grupo de cómics infranarrativos, encontraríamos secuencias de viñetas que, pese a contener elementos figurativos, no articulan una narrativa convencional. Queda entonces en manos del lector la posibilidad de conferir un significado narrativo coherente a estas historietas, y en las palabras con que Groensteen lo plantea se adivina cierto paralelismo con la teoría propuesta por Fludernik:

The comics reader takes semantic and narrative coherence for granted. S/he presumes that «the positioning of any panel necessarily has some point». When images set out consecutively fail to offer any immediate coherence, the reader is naturally inclined to minimize what seems like a «breach of contract» by formulating hypotheses intended to confer intelligibility on the string of panels - to convert an amalgam into a narrative sequence. It is only when these attempts fail that $\mathrm{s} /$ he makes the decision to assign these images to the always improbable category of infranarrative comics. ${ }^{19}$

17 Groensteen, T. Op. Cit.

18 Ibid.,p. 12. [«¿Qué es exactamente, entonces, lo que vemos en una página de cómic compuesta de imágenes abstractas? Dos cosas que deben distinguirse entre ellas. En primer lugar, el contenido visual: colores, líneas, formas organizadas en motivos. Estas "imágenes" abstractas interactúan entre ellas. Establecen relaciones de posición, contigüidad, intensidad, repetición, variación o contraste, así como relaciones dinámicas de ritmo, entrelazamiento, etc. En principio, nada en esta lista pertenece a lo narrativo, razón por la que me he referido a ellas como una serie, en lugar de como una secuencia, de imágenes. [...] En segundo lugar, lo que muestra una página de cómic abstracto es el aparato espacio-tópico de los cómics (al que nos referiremos como aparato). Este es el espacio delimitado y compartimentalizado, dentro del que las viñetas entran en relaciones espaciales y se componen como una totalidad orgánica»].

19 Ibid.,p. 19. [«El lector de cómic asume como algo dado la coherencia semántica y narrativa. Él/Ella supone que «la ubicación de una viñeta necesariamente tiene un motivo». Cuando las imágenes que se suceden de forma consecutiva no ofrecen una coherencia inmediata, el lector está naturalmente inclinado a minimizar lo que parece una "ruptura de contrato" formulando hipótesis con la intención de conferir inteligibilidad en la cadena de viñetas convirtiendo una amalgama en una secuencia narrativa. Es solo cuando estos intentos fallan que él/ella toma la decisión de asignar estas imágenes a la improbable categoría de los cómics infranarrativos»]. 
En ese territorio, todavía apenas cartografiado, delimitado por lo abstracto y lo infranarrativo - o vanguardista, o posnarrativo - se mueve con comodidad la obra de García-Alén, que puede servirnos como brújula para explorarlo.

Iniciaremos ese periplo en el extremo más alejado de lo narrativo, introduciéndonos en el último cómic del volumen Perlas del infierno ${ }^{20}$ donde encontramos algunas páginas que resultan prácticamente imposibles de narrativizar. En ellas observamos una composición de viñetas distribuidas sobre rejillas regulares donde se muestran una serie de formas, que asumen siempre una paleta de colores limitada —azul, salmón, rojo- y presentan cierta continuidad entre algunos de sus trazos.

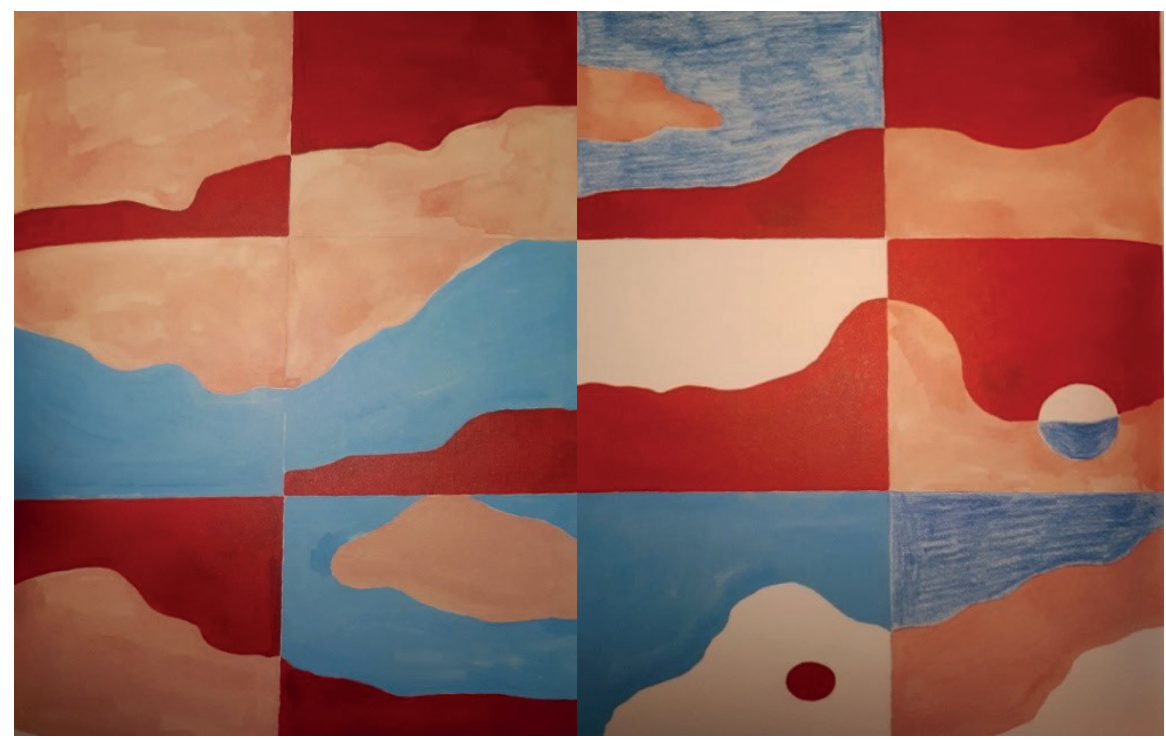

FIG. 5. Páginas de «5» en Perlas del infierno.

Vigo, Fosfatina Ediciones, 2014.

No existe figuración ni personajes antropomórficos en ellas, no existen bocadillos ni cartuchos de texto; la página se ve reducida a algunos de los elementos que Groensteen identifica como el aparato formal básico del cómic: las imágenes organizadas en series dentro de un multimarco, las líneas y los colores. Sobre ellos recae el peso de dotar de ritmo, contraste y coherencia a una sucesión de imágenes que quizá invita al lector a observarla como un todo en lugar de a recorrer con la mirada sus viñetas. Aunque nos enfrentemos a una rejilla convencional delimitada por áreas rectangulares, el patrón de progresión en $\mathrm{Z}$ que aplicamos siguiendo el esquema de lectura narrativa no produce los resultados habituales en ausencia de una representación figurativa registrada en instantes sucesivos. Podemos observar una continuidad de ciertos trazos que se prolongan horizontalmente entre las viñetas de una

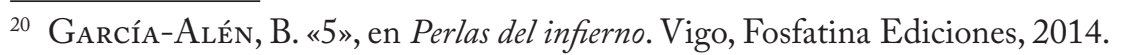


misma fila, pero esa continuidad espacial no se asemeja a la continuidad temporal prototípica que tiene lugar entre viñetas y no es narrativizable en los mismos términos.

Estas páginas habitan la frontera del medio y su condición podría resultar incierta al verse descontextualizadas. En esa situación, a la dificultad en su proceso de narrativización - debida a la ineficacia de la aplicación de los esquemas asociados a la lectura de historietas convencionales-, el observador podría sumar otra adicional para identificarlas como páginas de cómic.

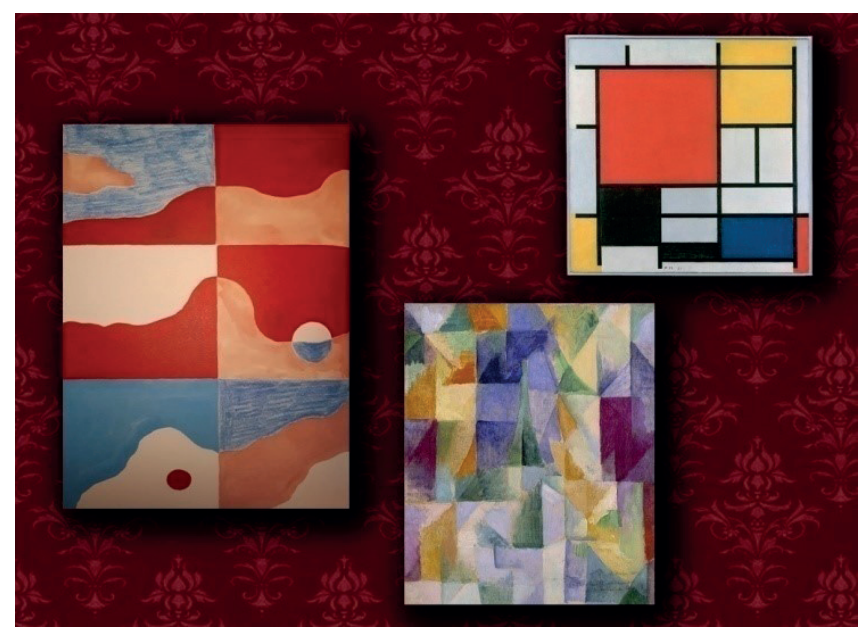

FIG. 6. Pared de una galería de arte imaginaria en la que una página de Alén comparte espacio con Windows Open Simultaneously (First Part, Third Motif) (Robert Delaunay, 1912) y Composición en rojo, amarillo, azul y negro (Piet Mondrian, 1921).

No debemos sin embargo entender esta ambigüedad — recordemos: salvable siempre por el contexto- como algo negativo, como una intromisión ajena que deteriorara la pureza del medio. Todo lo contrario, el potencial del cómic para apropiarse de cualquier tipo de manifestación icónica, esa ilimitada porosidad de sus fronteras, es una de sus mayores virtudes y un rasgo a destacar como definitorio.

En contraste con la literatura, el cómic incorpora en su recepción la experiencia natural de observación propia del ser humano. El esquema cognitivo "viewing» se aplicaría de modo transparente cuando nuestra mirada recorre una página de cómic deteniéndose en cada una de sus viñetas y su manifestación prototípica supondría una mínima desviación de esa vivencia cotidiana. El estilo figurativo representaría entonces la forma más directa de naturalizar la dimensión icónica del cómic. Encontrar en sus viñetas una representación en perspectiva tridimensional de elementos reconocibles que evolucionen siguiendo un orden cronológico facilitaría al lector el proceso de narrativización. Teniendo esto en cuenta 
podemos observar cómo, superando esa abstracción imposible de narrativizar, se pueden introducir en el cómic elementos que animen y favorezcan esa tarea.

Consideremos alguna página del cómic «La visión» que García-Alén publicó también en Perlas del infierno. ${ }^{21}$ En esta historieta una figura indefinida afronta un viaje - difícil de justificar desde una perspectiva teleológica - por un espacio tridimensional en el que reconocemos puertas, escaleras y la sugerencia de cierto espíritu flaneur, de cierta curiosidad, que dota a esa forma de rasgos proto-antropomórficos. Aplicando los esquemas cognitivos correspondientes al nivel I del modelo de Fludernik reconocemos ciertos gestos familiares en la figura cuando se asoma temerosa a una esquina antes de atreverse a franquearla $o$ persigue jugueteando - como un niño o una mascota - a otra figura circular también dotada de vitalidad, o baja escaleras pese a carecer de extremidades que se lo permitan, o se detiene a observar un agujero cambiante por el que se ha introducido el objeto de su persecución.

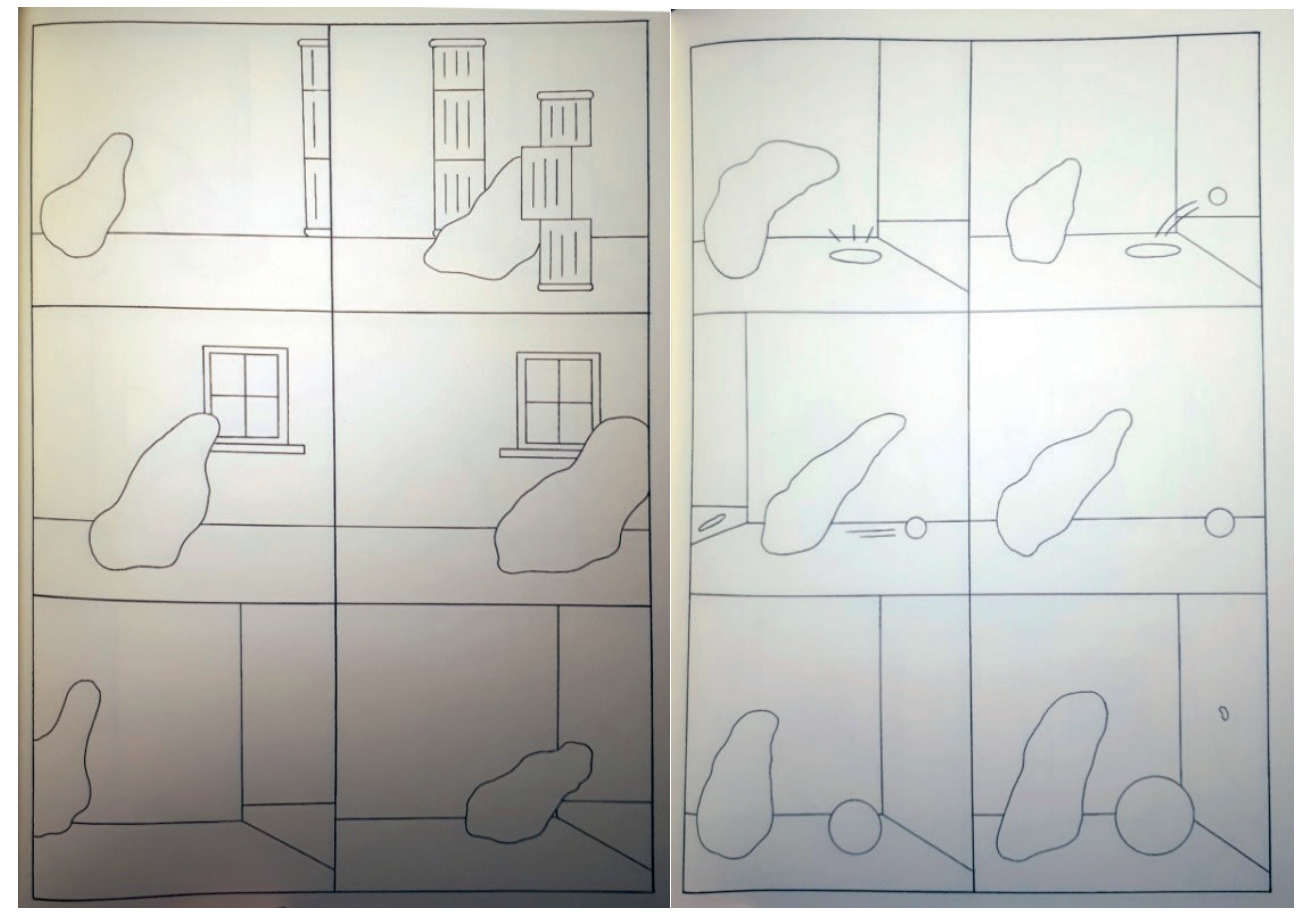

FIG. 7. Páginas de «La visión», en Op. cit.

En esta historieta, García-Alén recurre de nuevo a componer la página con una rejilla de seis viñetas pero, en comparación con las que comentamos previamente, aquí la aplicación del esquema de lectura en $Z$ sí ofrece un resultado satisfactorio. El reconocimiento de una espaciotemporalidad que transcurre sucesivamente entre viñetas, avanzando según el patrón lineal propio de nuestra experiencia humana, anima el proceso de narrativización. Aunque

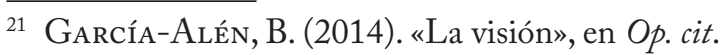


todavía quede muy lejos de presentar una trama definida en la que se pueda atribuir a los personajes existentes una lógica actancial que guíe sus actos e instaure una relación causal entre los eventos en los que participen. Pero en esa inscripción dentro de un espacio y un tiempo reconocibles y en la identificación de una actitud cuasihumana se intuye y se empieza a generar lo narrativo, todavía a un nivel muy básico.
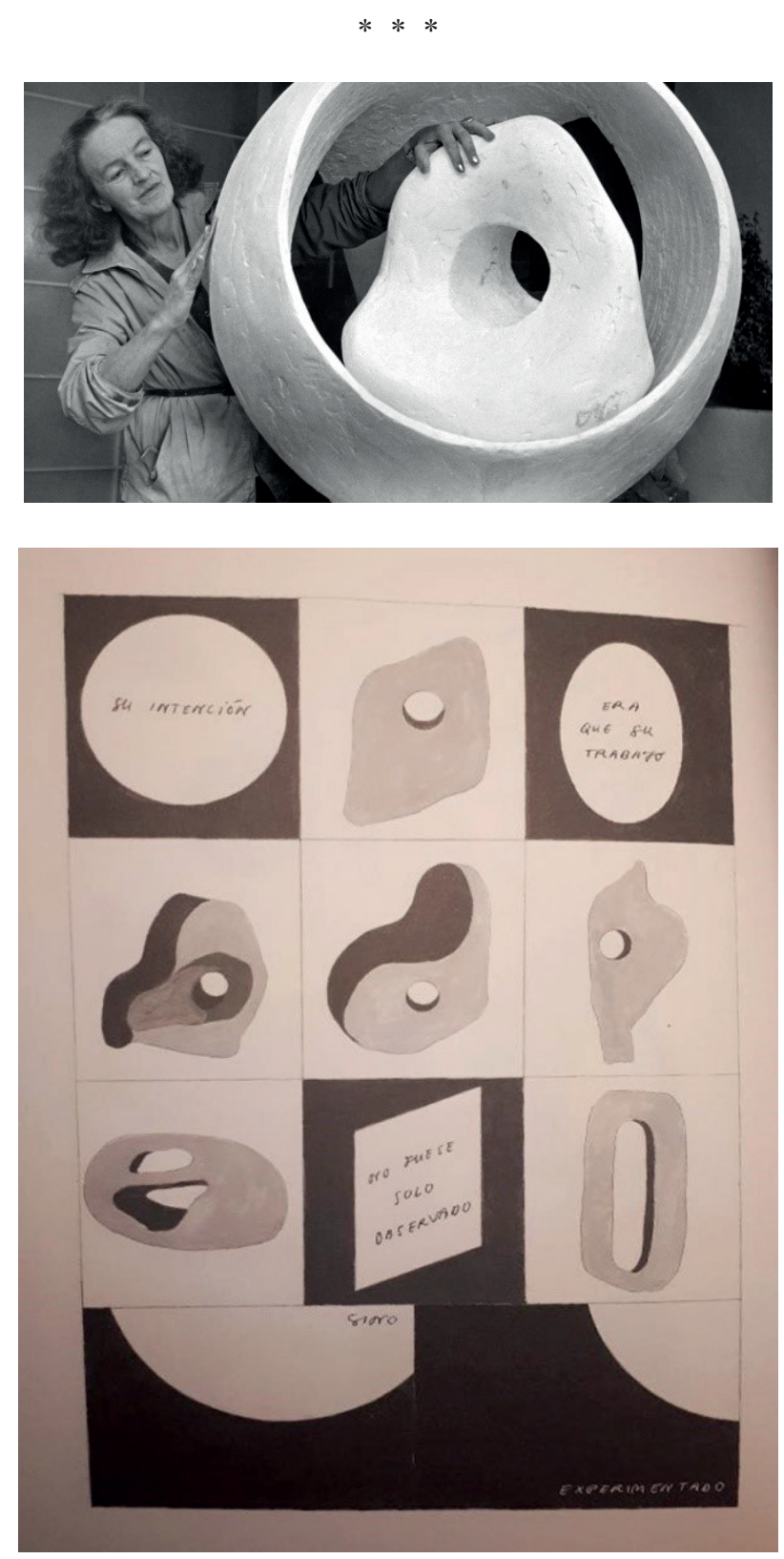

FIG. 8. Fotografía de Bárbara Hepworth con una de sus esculturas (arriba). Página de «Figuras en el paisaje», en Nueva Mistica de Vigo. Vigo, Noche líquida, 2017 (abajo). 
Es en otra de sus obras, la más extensa hasta la fecha, titulada Nuevas Estructuras, ${ }^{22}$ donde quizá se aprecien mejor los rasgos más frecuentados por el estilo de Begoña García-Alén. Pero antes de centrar nuestra atención en ella, si dedicamos un momento a revisar unas viñetas de otro cómic distinto, «Figuras en el paisaje», publicado dentro de Nueva mistica de $V_{i g o,}{ }^{23}$ puede ser posible apuntar un impulso recurrente en la poética de la autora. ${ }^{24}$

En este cómic García-Alén traza un retrato biográfico de la artista Barbara Hepworth y de su aproximación a la escultura, incidiendo en un aspecto que parece también reflejarse en su propia aproximación al cómic y que evoca involuntariamente el concepto de experiencialidad de Fludernik. García-Alén afirma que la intención de la escultora era lograr que su obra, más que observada, fuera experimentada. En los cómics de García-Alén vamos también a afrontar esa inmersión del lector en la obra tan alejada de la observación pasiva.

En Nuevas estructuras esa propiedad magnética de la obra que atrae al lector a un nivel más profundo que el de mero observador, invitándole a experimentarla, haciéndole copartícipe y responsable en su construcción, se manifiesta de manera recurrente y de diversos modos.

Si observamos la forma en que García-Alén emplea los cartuchos de texto — tradicionalmente reservados a la dimensión diegética - en los diferentes capítulos en los que se divide el cómic podemos apreciar esa cualidad inmersiva a la que nos referíamos. A este respecto las observaciones que vamos a elaborar a continuación responden a un intento de ampliar el siguiente comentario que Breixo Harguindey dedica a la voz de los personajes en esta obra:

A falta de referencia visible, estos se expresan mediante cartuchos y no globos, una sola voz por capítulo que corresponde o bien al propietario de la vivienda dirigiéndose a los técnicos como vosotros o ellos, o bien a algún técnico refiriendo su propia experiencia en primera persona, nosotros y yo, o - en el interludio poético del sueño - a la propia narradora que reflexiona sobre el «hombre». Estos juegos deícticos que señalan a personas y lugares interpelan directamente al lector,

22 García-Alén, B. Nuevas estructuras. Barcelona, Apa-Apa Cómics, 2017.

${ }^{23}$ García-Alén, B. y Navazas Fernández, J. «Figuras en el paisaje», en Nueva Mística de Vigo. Vigo, Noche líquida, 2017.

${ }^{24}$ Esta alusión no significa en ningún caso que estemos postulando una intención consciente por parte de la autora, sino reconociendo en la propia obra, en el texto de Nuevas estructuras, una serie de rasgos que apuntan en una determinada dirección. Desde una perspectiva crítica intentar delimitar la intención de un autor al crear su obra puede indirectamente señalar el camino que lleve a asumir como único sentido válido ese «querer decir» que en ocasiones se aleja radicalmente de la realidad que viven los receptores de esa obra. Asumir una perspectiva de este tipo podría resultar reduccionista al conllevar la sobrevaloración de una lectura - la certificada por el autor - sobre todas las demás, que se verían condenadas a asumir la categoría de erróneas. Desde nuestra concepción estética no existe una lectura que se deba a imponer sobre el resto ya que todas ellas - siempre que estén justificadas con argumentos - enriquecen y alargan la vida de una obra. Es importante señalar también la diferencia existente entre que un autor declare abiertamente sus intenciones - que como señalábamos pueden no encontrar correspondencia directa en la experiencia de la obra por parte de sus receptores- y que un crítico le atribuya alguna y pretenda validarla a posteriori, lo que resultaría un ejercicio de arrogancia bastante cuestionable. Nada más lejos de nuestra intención. 
alteran una y otra vez su posición subjetiva a través del lenguaje, subvierten así el empleo tópico de los pronombres al reservar la primera y segunda persona para el relato y la tercera para la poesía. ${ }^{25}$

Ese énfasis que Breixo Harguindey dedica a la ubicación múltiple del sujeto lector mediante el juego de perspectivas que desarrolla la autora se puede ampliar señalando que, independientemente del lugar al que se vea desplazado, ese movimiento obedece a una fuerza de atracción que lo empuja hacia el interior del cómic compartiendo la subjetividad y la capacidad de agencia de sus protagonistas. En ese juego los deícticos asumen un papel fundamental por sus peculiaridades enunciativas, por ser «un recurso puramente formal, vacío de cualquier referencia semántica, por medio del cual el sujeto de la enunciación se hace presente en el propio mensaje». ${ }^{26}$ Su empleo no remite a un existente en el mundo exterior al lenguaje, carecen de un anclaje referencial, constituidos exclusivamente de materia lingüística adquieren sentido solo en el momento de ser pronunciados: solo al decir «yo» lo lleno con mi persona y se convierte en aquel que dice "yo». Y esa condición descarnada aflora en la obra de García-Alén para abrir pasadizos por los que involuntariamente el lector se adentre.

En el primer segmento del cómic, titulado «La casa», la autora reserva el uso del cartucho de texto a la voz del participante en un monólogo — que en ocasiones se asemeja a un diálogo truncado-; lo restringe a las palabras de bienvenida del anfitrión que recibe a un grupo de constructores que van a reformar su casa. Esa voz se dirige a un «vosotros», a una pluralidad de receptores que no se manifiestan nunca explícitamente, que carecen de representación. Se genera así una indeterminación comunicativa, un espacio vacío en el que caben múltiples receptores a la apelación de ese anfitrión y, entre ellos, el propio lector del cómic. El empleo del tiempo presente, propio de la dimensión mimética, en ese discurso del dueño de la casa fuerza su simultaneidad con el tiempo de lectura y aparenta una interpelación directa al lector, de manera que se fomenta así su ingreso en el grupo de personajes constructores. García-Alén desplaza aquí el monólogo del personaje desde el espacio mimético al diegético, porque el uso que da a la imagen de la viñeta — que comentaremos más adelante- no permite el anclaje indexical de los bocadillos tradicionales. Al no disponer de una representación corporal sobre la que sostenerse: el personaje ausente solo puede hablar de un modo impersonal, desde el cartucho. Y en esa omisión tan infrecuente, y que además resulta plural — recordemos: «vosotros»—, el lector se puede proyectar con una facilidad que no encontraría en circunstancias normales. Podríamos incluso aventurar que, en lugar de proyectarse, se ve absorbido en ese vacío que deja la representación figurativa del personaje.

En el segundo episodio, titulado «El proyecto», es esa voz — previamente muda- de los constructores quien toma la palabra y se hace responsable de un discurso diegético tradicional desplegado también sobre los cartuchos de texto. De nuevo en plural —aunque según avance el relato se reducirá a un solo «yo»-, empleando como persona un «nosotros» en el

25 Harguindey, B. «Nuevas Estructuras», en 13 Millones de Naves. Disponible en https://www.13millonesdenaves.com/nuevas-estructuras/ (última consulta 01/11/18).

${ }^{26}$ Garrido Domínguez, A. El texto narrativo. Madrid, Editorial Síntesis, 1996, p. 150. 
que involuntariamente el lector se incluye, al pronunciarlo durante su lectura. En este capítulo se revive ese primer encuentro con el anfitrión de la casa al que asistíamos previamente desde la perspectiva de los recién llegados y es muy interesante observar cómo representa García-Alén ese momento en la única página donde aparece un bocadillo de texto totalmente vacío en boca del personaje al que se daba voz en el primer segmento.

Esa cesión del aspecto diegético del cómic a voces que lo relatan desde el interior del mundo ficcional se rompe temporalmente en el tercer bloque para ceder el papel de narrador a una voz ajena a él. Pese a titularse «El sueño» en las páginas que componen este episodio, al contrario que en el resto, no se integra ninguna subjetividad perceptible. En ese discurso impersonal se propone una reflexión de carácter general sobre el trabajo del hombre que sirve de contrapunto a las otras tres voces que vertebran el relato desde diferentes perspectivas.
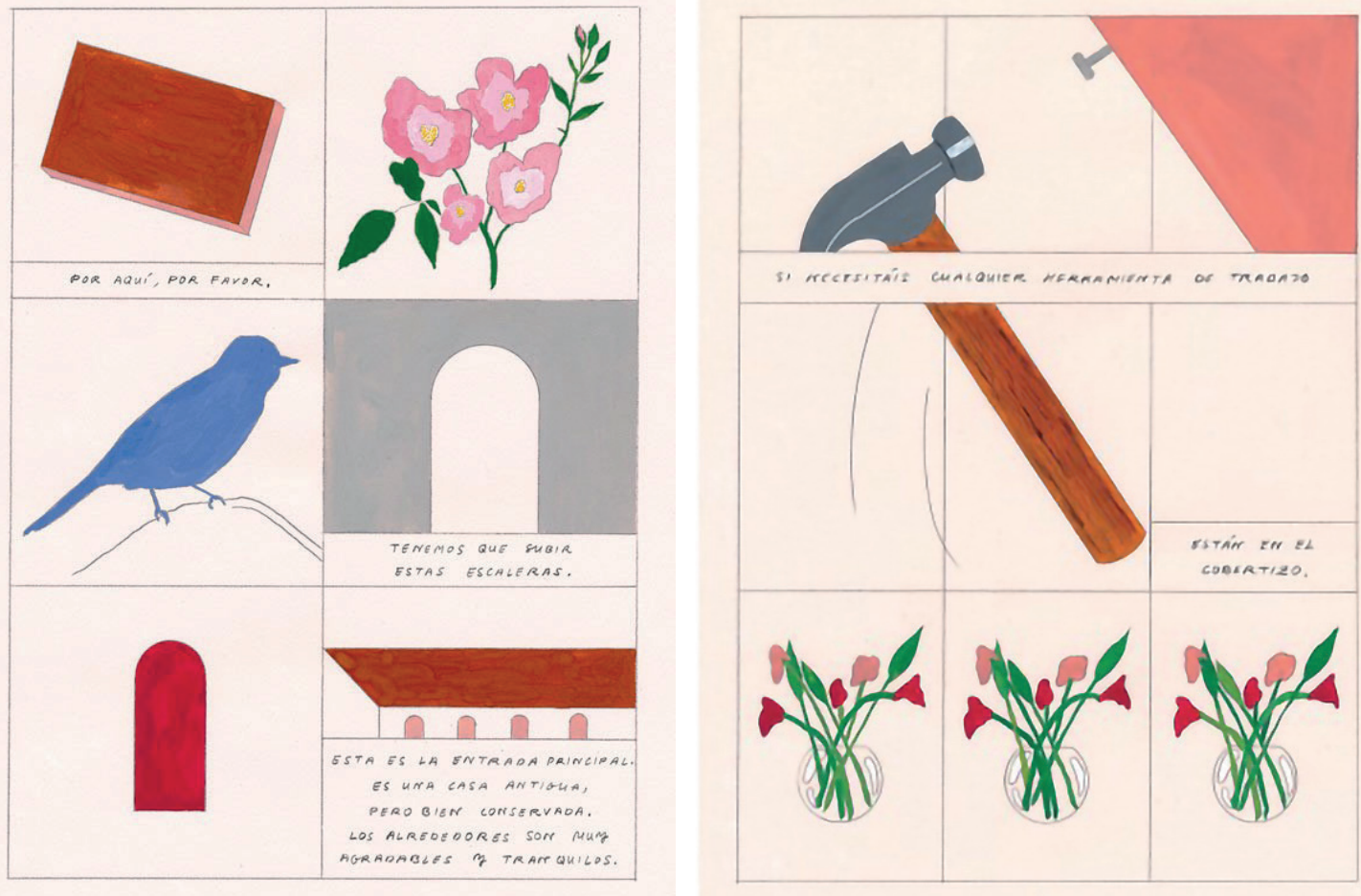

FIG. 9. Páginas del capítulo "La casa" de Nuevas estructuras donde se entabla un diálogo unidireccional del anfitrión que recibe al grupo de constructores a su llegada.

En el cuarto y último segmento, «La construcción», es el anfitrión de la casa quien asume el papel de narrador, proyectando su voz desde el espacio diegético del cartucho de texto —al contrario de lo que sucedía en el primero, donde esa misma voz sostenía un monólogo desde la dimensión mimética-. En esta ocasión se crea de nuevo un espacio para el lector que 
invita a su identificación con los constructores. Su llegada a la casa coincide con el comienzo de la lectura, el proceso de edificación transcurre en paralelo a su avance y la finalización del proyecto y marcha de los técnicos tienen lugar en la última página del cómic, en el mismo momento en el que el lector concluye la obra y también la deja atrás.

1. «La casa»

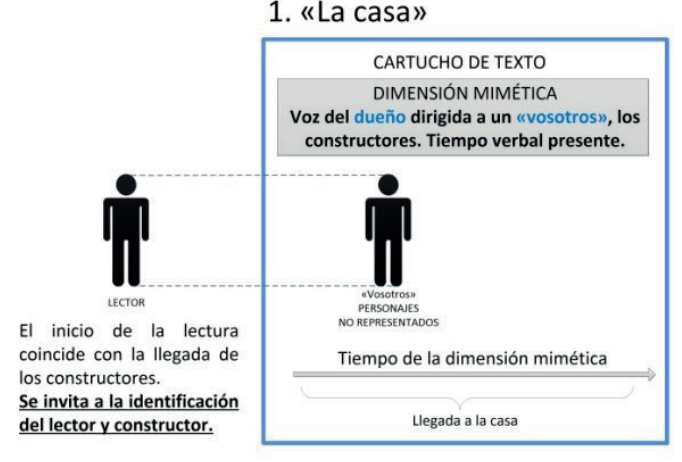

3. «El sueño»

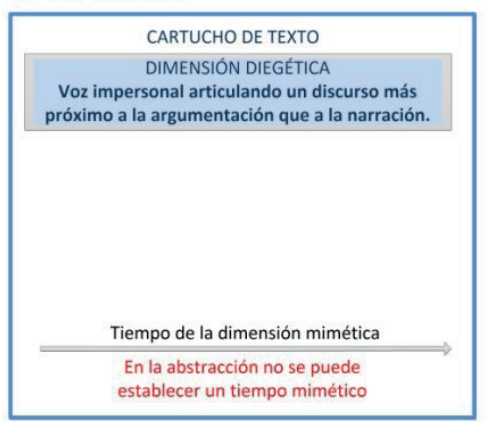

\section{2. «El proyecto»}

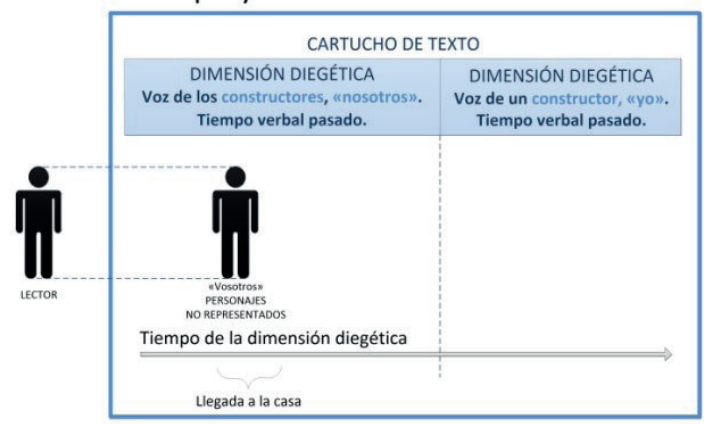

4. «La construcción»

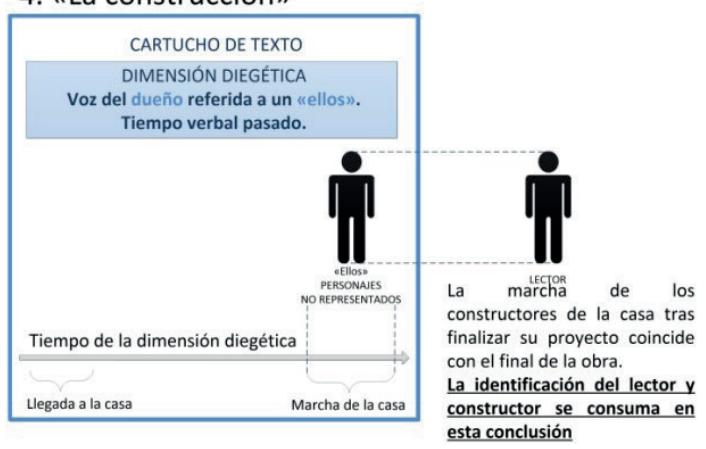

FIG. 10. Diferentes modos de incorporación del lector a la dimensión diegética de Nuevas estructuras. Elaboración propia.

El relato que se va construyendo de este modo no ofrece obstáculos insalvables para su narrativización. Aunque existe un alto grado de despersonalización en ellos - carecen de nombre propio, y en la dimensión mimética no se ven representados-, los personajes existen e interactúan entre sí de forma reconocible, habitando una trama lineal perfectamente asimilable a la división en tres actos convencional - llegada, construcción, marchaLa adopción del multiperspectivismo, al contrario que en otros relatos donde se pone al servicio de una cosmovisión relativista, sirve aquí para reforzar su arquitectura: lo que el lector presencia en primera persona en el episodio inicial coincide con lo que cuentan los constructores y el anfitrión en el segundo y el cuarto. La trama, ya simple de por sí, ve apuntalada su sencillez con esa reiteración y es quizá esa minimalización de los elementos que sostienen la estructura narrativa lo que puede producir cierta extrañeza en el lector. Pero su presencia es palpable aunque no lo sea tanto su sentido _ ¿por qué remodelar la casa? ¿Cuál es la función de esa nueva estructura? - y no debe producirse confusión entre ambos. La pérdida del sentido no significa que la narrativa también haya resultado evacuada del texto. 
Si prestamos ahora atención a la narratividad en la dimensión mimética de la obra descubriremos algunos de los aspectos más innovadores de la poética de Begoña García-Alén. Las imágenes de sus viñetas se distancian de forma notable de la figuración prototípica para limitarse a ofrecer en muchos casos representaciones de objetos o elementos aislados, sin fondos tridimensionales que sirvan para contextualizarlos. La prioridad de la representación general del espacio se cede a lo particular, adquiere peso una focalización subjetiva en lo concreto que evoca en el lector una experiencia perceptiva a un nivel de consciencia más profundo que el correspondiente al esquema cognitivo «viewing», asociado a nuestro modo habitual de mirar el mundo. En esa forma de presentar el plano mimético, la mirada del sujeto lector aparenta acceder directamente al nivel de la acción en el relato sin mediación alguna. Estamos acostumbrados a que en la viñeta se nos presente una perspectiva tridimensional que indefectiblemente asumirá un foco sobre el que se fuerce la ubicación del espectador y que jamás podrá coincidir con su posición en el mundo exterior durante su acto de lectura: el lector observa siempre a través de otro sujeto observador. En las viñetas de García-Alén no es posible detectar esa mediación y la mirada del lector parece penetrar hacia el interior de la viñeta directamente, sin filtro alguno, accediendo a una cualidad primaria de lo representado.
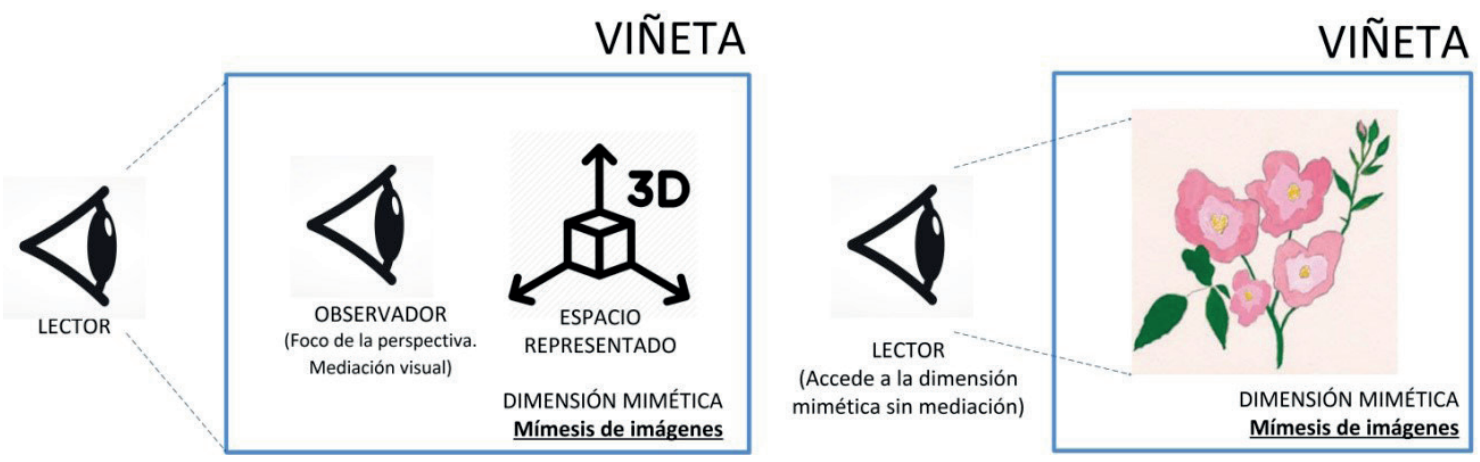

FIG. 11. Acceso mediado a la dimensión mimética figural y acceso directo en el caso de Nuevas estructuras. Elaboración propia.

En este tipo de representación el papel del patrón de lectura en $Z$, aunque sigue resultando posible de aplicar, pierde relevancia. La temporalidad sucesiva implícita en la página de cómic tradicional se diluye al percibir la realidad a impulsos aislados en las páginas de García-Alén y el orden en su recepción deja de ser algo pautado. Observar primero una u otra imagen no altera el sentido de la lectura y solo en ciertas ocasiones una secuencia de viñetas adquiere significado parcialmente, al aplicar el patrón de sucesividad convencional. Liberado de esa restricción, el lector ve orientado su devenir sobre la página por los cartuchos de texto, en los que el flujo narrativo diegético sí mantiene la linealidad que no conserva el mimético, y su ubicación puede marcar un camino a seguir. El abandono de esa guía rígida que supone el patrón en $Z$ alienta de nuevo la transformación del lector en un constructor que comparte la cimentación de las nuevas estructuras que va erigiendo García-Alén. 

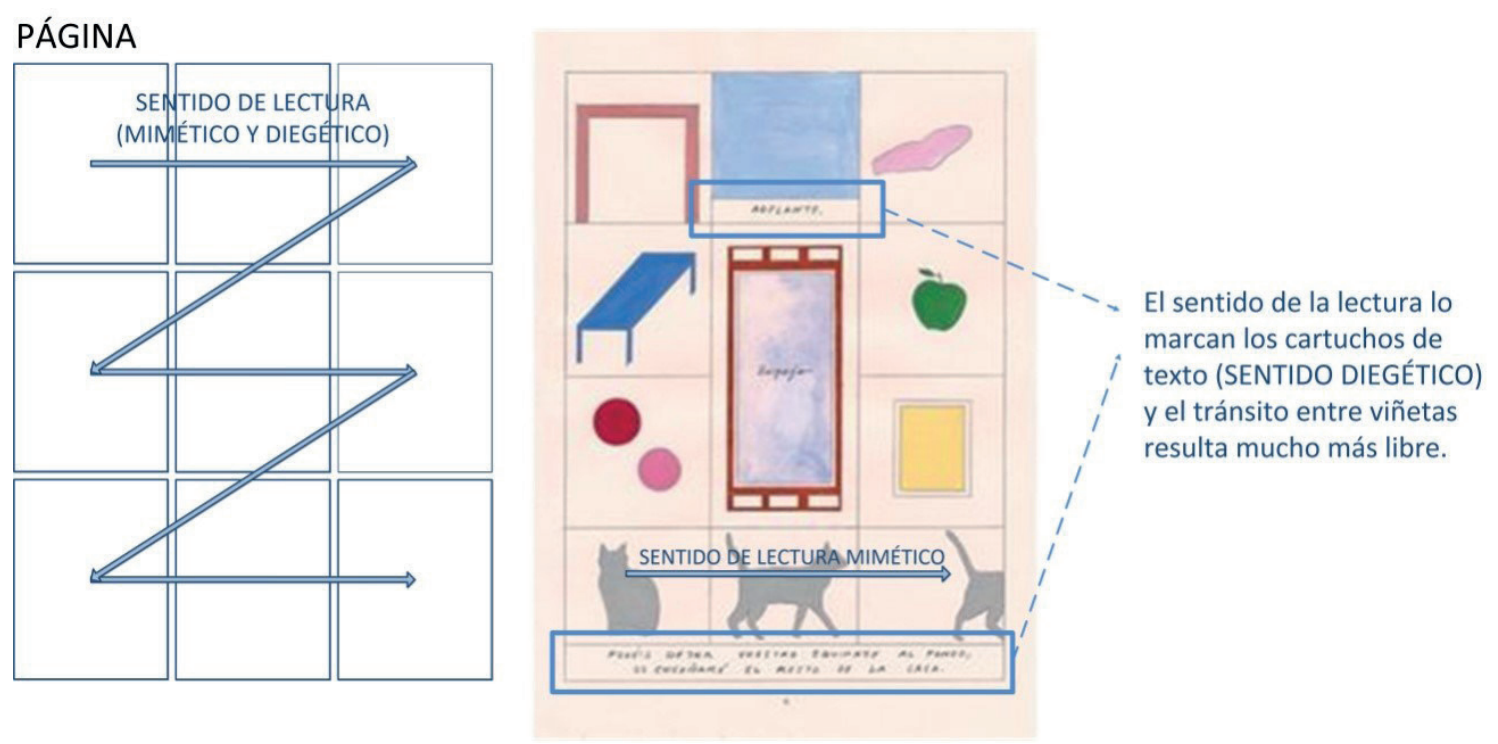

FIG. 12. Sentido de lectura a nivel mimético y diegético en una página de Nuevas Estructuras. Elaboración propia.

Al evitar construir un espacio referencial perfectamente definido que sirva de sustento a la dimensión mimética, las imágenes de las viñetas se ubican a mitad de camino de la abstracción. Por sí mismas resultarían difíciles de entender como relato, su narrativización requeriría un inestimable aporte del lector que probablemente se manifestaría insuficiente. Al contrario de lo que sucede habitualmente - cuando la dimensión mimética asume el peso del componente narrativo llegando a prescindir por completo del espacio diegético puramente verbal-, en el cómic de García-Alén el mundo ficcional se sustenta sobre la dimensión diegética — que aporta parcialmente esa estabilidad referencial de la que la imagen carece en este caso- y el juego habitual que establece la historieta entre voz y representación se ve sustituido por otro entre voz e impresión.

Es notable también la ausencia de personajes humanos que, unida a esa representación icónica centrada en el objeto, subraya la subjetividad de la dimensión mimética. Del mismo modo que sucedía con el empleo de los deícticos «nosotros» y «vosotros», esta despersonalización permite que la introducción del lector en el texto se produzca sin necesidad de proyectarse sobre un personaje concreto. No tiene lugar aquí un proceso de identificación, sino uno muy distinto de incorporación en el que el lector queda incluido dentro de esos sujetos plurales y su mirada atraviesa la página, accediendo directamente a ella.

Atendiendo a estas reflexiones podemos afirmar que Nuevas estructuras, aunque no responda fielmente a los esquemas cognitivos tradicionales que empleamos en la lectura de cómic, resulta narrativizable una vez superadas ciertas dificultades, principalmente a nivel mimético. En este caso, la articulación narrativa adquiere un mayor peso en la dimensión diegética del cómic, en ese relato multiperspectivista, que muestra una elevada coherencia 
interna aunque no ofrezca un sentido claro. Ese vacío o la ausencia de una clausura definida que facilite el trabajo al lector - no es el caso de Nuevas estructuras, perfectamente clausura$\mathrm{da}$ - no deben confundirse con la ausencia de narratividad: podemos hablar de vanguardia, posnarratividad o infranarratividad, pero en ninguna de esas categorías estamos excluyendo la narrativa. Es precisamente en esos espacios vacíos, en las ambigüedades, en la pluralidad o indistinción subjetiva donde el lector se ve atrapado y debe realizar un esfuerzo personal para salir con éxito del texto. La función del detective - del observador que analiza pistas y saca conclusiones desde la seguridad de la distancia, desde el exterior ajeno al crimenque, de forma indirecta, le asignaba el modelo estructuralista, se ve sustituida aquí por una incorporación directa a la experiencia de la historieta en la que el lector muta en personaje y coautor; no ya en detective, sino simultáneamente en asesino y víctima. Se convierte en un constructor que llega al cómic - a la casa de otro, de ese autor que actúa siempre como anfitrión y en cuyo ofrecimiento coinciden el hogar y la obra- para añadir la estructura que le falta - una nueva ala de la casa, un sentido textual, una experiencia- y que la abandona satisfecho, tras haber realizado ese esfuerzo, habiendo cumplido con su parte del trabajo, cuando pasa la última página.

El papel de los teóricos, como el de los lectores, experimenta en paralelo esa transformación y desde la narratología también resulta necesario ampliar la edificación que levantó el estructuralismo para añadir anexos donde puedan habitar nuevos y bienvenidos inquilinos. Siguiendo la estela de las propuestas de esos artistas que se aventuran a explorar nuevos territorios, las aportaciones de nuevas perspectivas teóricas, como las que pueden of recer las corrientes narratológicas postclásicas, deberían encontrar un hospitalario acomodo en esas nuevas estructuras. 


\section{Bibliografía}

Alber. J y Fludernik. M. «Introduction», en Postclassical Narratology. Approaches and Analyses. Columbus, The Ohio State University Press, 1999.

Fuudernik, M. Towards a Natural Narratology. London, Routledge, 1996.

García-Alén, B. Nuevas estructuras. Barcelona, Apa-Apa Comics, 2017.

—Perlas del infierno. Vigo, Fosfatina Ediciones, 2014.

García-Alén, B.y Navazas Fernández, J. Nueva Mistica de Vigo. Vigo, Noche líquida, 2017.

Garrido Domínguez, A. El texto narrativo. Madrid, Editorial Síntesis, 1996.

Groensteen, T. Comics and Narration. Jackson, University Press of Mississippi, 2011 [2013].

Gubern, R. El lenguaje de los comics. Barcelona, Ediciones Península, 1972.

Harguindey, B. «Nuevas Estructuras», en 13 Millones de Naves. Disponible en https:// www.13millonesdenaves.com/nuevas-estructuras/ (última consulta 01/11/18).

Herman, D. «Scripts, Sequences, and Stories: Elements of a Postclassical Narratology», en PMLA, vol. 112, n. ${ }^{\circ} 5$ (octubre 1997), pp. 1046-1059.

Jiménez Varea, J. Narrativa gráfica. Narratología de la historieta. Madrid, Editorial Fragua, 2016.

Muñoz Fernández, H. «Notas sobre el cómic más allá de la narración» (mayo 2017). Disponible en https://es.paperblog.com/notas-sobre-el-comic-mas-alla-de-la-narracion-4364575/ (última consulta 22/11/18).

Vilches, G. «La vanguardia y su crítica», en Revista Kamandi (7 de diciembre de 2016). Disponible en http://www.revistakamandi.com/2016/12/07/la-vanguardia-y-su-critica/ (Última consulta 15/10/18). 